\title{
AUDIT ANALYSIS PROJECTS IN IDEA
}

\section{USING IDEA TO TEACH DATA ANALYSIS}

\section{Dr. Connie O'Brien}

Minnesota State University Mankato connie.obrien@mnsu.edu 


\section{AUDIT ANALYTIC PROJECTS IN IDEA PRESENTATION OUTLINE}

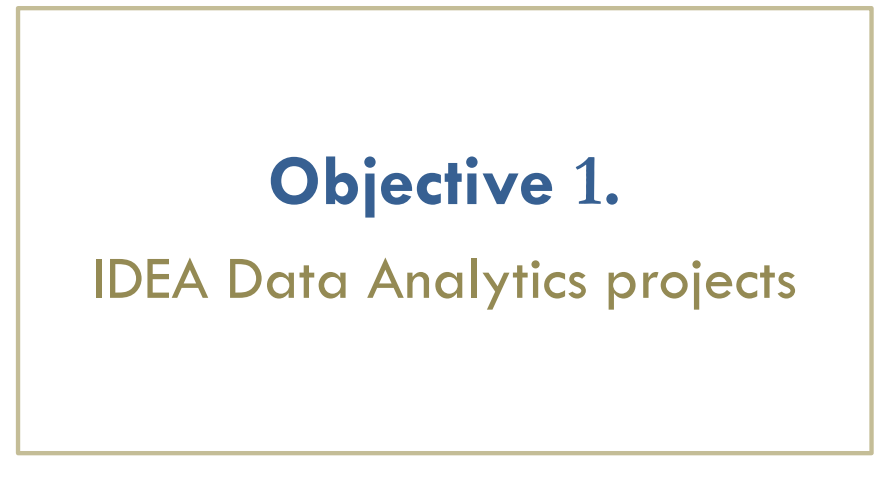

\section{Objective 3.}

Projects and procedures in IDEA

\section{Objective 2.}

IDEA Data analysis projects and students

\section{Objective 4.}

Tips and Tricks to successfully Implementing IDEA in courses 


\section{IDEA DATA ANALYTICS PROJECTS BENEFITS}

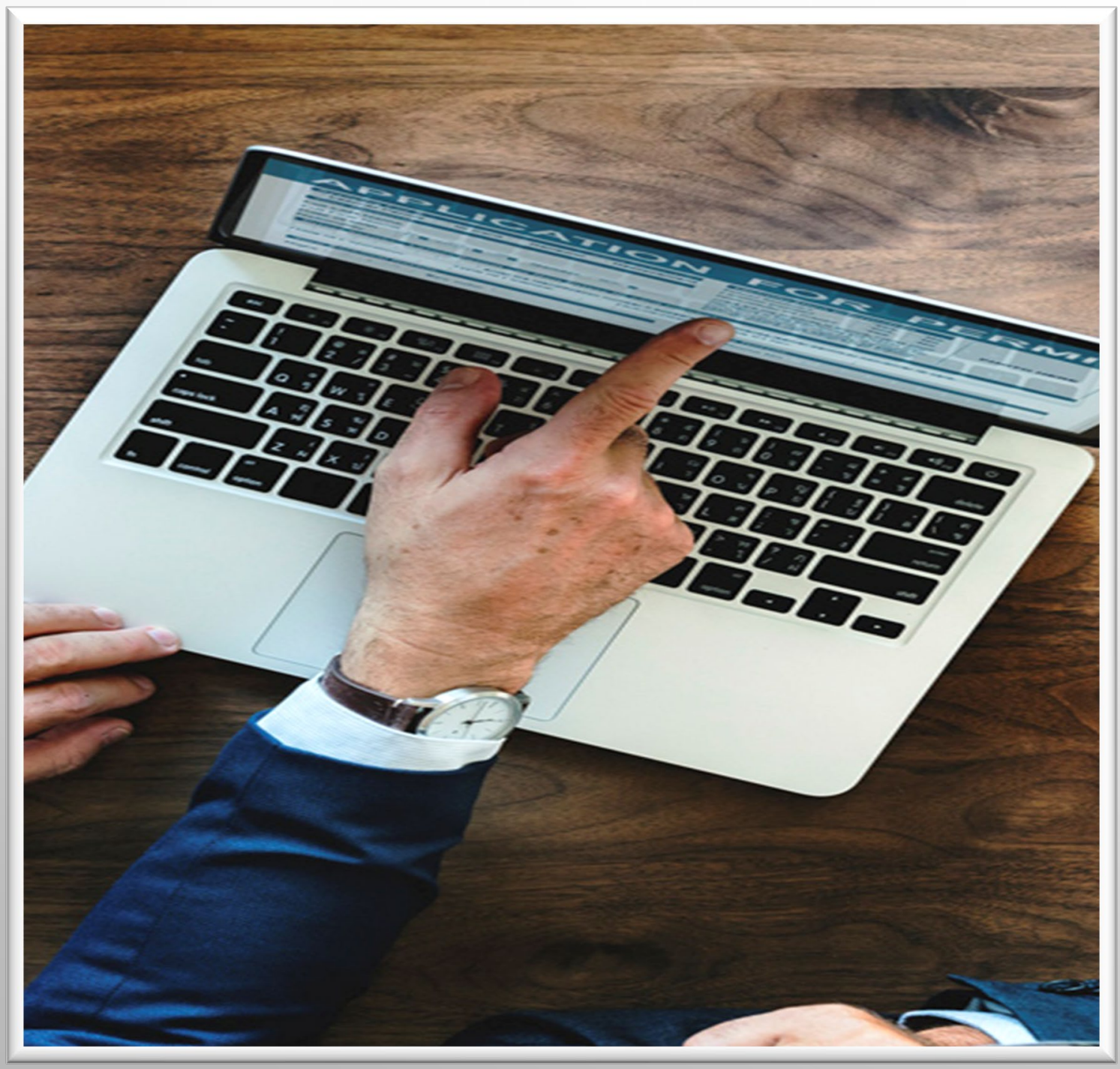

- Incorporates experiential learning opportunities the course.

- Creates an interactive approach to teaching audit concepts and cycles.

- Adaptable for any teaching modality (online, hybrid, face-to-face, etc.) 


\section{IDEA DATA ANALYSIS PROJECTS AND STUDENTS}

Students Benefits:

- Acquire experience using data analytical software (IDEA).

- Develop their ability to evaluate data and gain useful insights about the relationships that exist within.

- Develop critical thinking skills as they expand on the meaning of the results and the findings to solve problems.

- Prepare students for employers and professional exams. 


\section{PROJECTS AND PROCEDURES IN IDEA}

- COMMON PROCEDURES USED IN IDEA PROJECTS:

- Control total - Net total of a specific Field

- Felid Statistics - Net total, Absolute value, Minimum value, Maximum value, \# of Records, \# of Zero items, etc.

- Sorting and indexing - Ascending, Descending, $>,<_{1}=$, etc..

- Stratify data

- Aging report

- Gap and Duplicate detection

- Sampling applications - random, stratified random, systematic

- Data manipulation logic functions such as $>,<,<>,=,==$, AND, Date, " ", etc. 


\section{PROJECTS AND PROCEDURES IN IDEA}

Initial posting:
Complete your assessment of the accounts receivable 2015 file utilizing IDEA to evaluate the
data and the effects on the financial statements. (You can use the workbook to guide you. My
suggestion is to go through aging on page 54 . You may also think of additional procedures on
your own.) Concisely document your objectives, tests, and analyze the financial statements of the
company. Clearly divide your analysis by each steps or procedure, with their analysis, and
supporting evidence as demonstrated in class.
Specifically:
- Develop objectives related to each of the tests you performed.
- Clearly relate each of the objectives to an assertion.
- Identify the audit procedure used
- Explain what the results tell about the condition of the financial statements.
Objectives need to specifically explain the purpose is. Do not combine objectives.
For example: Determine if all interest payments related to the loan have been recorded. to test
the completeness of the interest records, I vouched recorded interest payments to the monthly
interest invoices provided by the vendor. The recorded amount in the books was $\$ 2368$, while
the amount billed by the vendor totaled $\$ 2378$. Recorded monthly Interest payments were
understated by $\$ 10.00$. Record an additional $\$ 10.00$ of interest.

\section{- DISCUSSIONS:}

- DISCUSSION QUESTIONS ALLOW OTHER STUDENTS TO PROVIDE FEEDBACK ON HOW TO TEST AND ANALYSIS DATA.

- IT HELPS TO PROMOTE UNDERSTANDING AND PROVIDES PEER ASSESSMENT OF STUDENT WORK. 
- QUIZZES IN D2L:

- alternative to Writing assignments.

- quizZES CAN BE INDIVIDUAL OR GROUP QUIZZES.

- RANGE BETWEEN 5 AND 10 QUESTIONS.

- GUIDES STUDENTS THROUGH THE ANALYSIS PROCESS.

- EXAMPLE QUIZ:

\section{PROJECTS AND PROCEDURES IN IDEA}

- DIRECT EXTRACTION QUIZ (HTTP://TINY.CC/OJJMSZ)

\section{Idea Tutorial Quiz}

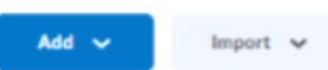

1 What is the purpose of refining and cleaning up the client data when we first obtain it? Multiple Choic

1 What is the balance of the clients trail balance (control total) that you are trying to get the data to match? (Do not.

3 How many records and what is the total value of the Accounts receivable file when you first imported the client Multiple Choic

4 How many records and what is the total value of the Accounts receivable file after you cleaned the client data? (Hi) 


\section{PROJECTS AND PROCEDURES IN} IDEA

\section{- IDEA PROJECTS:}

- THIS PROJECT IS SEMI GUIDED. STUDENTS ARE GIVEN A LIMITED AMOUNT OF DATA AND SOME CHECK FIGURES TO DETERMINE IF THE DATA IS CLEAN.

- AUDIT OF STARK COMPANY ACCOUNTS RECEIVABLE

- STUDENTS ARE PROVIDED LINKS TO DATA FILES

- $\quad$ LINKS TO EXAMPLE MEMOS

- $\quad$ LINKS TO EXAMPLE TESTS FOR ACOUNTS RECEIVABLE

\section{- EVALUATIONS}

- RELEVANCE OF EVIDENCE

- SUFFICIENCY OF EVIDENCE

- aNALYSIS OF THE EVIDENCE

- gRADE A SAMPLE PARAGRAPH ON GRAMMAR AS OPPOSED TO THE WHOLE DOCUMENT.

- $\quad$ ALLOW WRITTEN PROJECTS TO GROUP ASSIGNMENTS IN STEAD OF INDIVIDUAL.

\section{Auditing Accounts Receivable}

You have been engaged to audit a public. You and your partner have been assigned to examine the Accounts receivables. Your team leader has tasked you with:

1. Testing all relevant assertions

2. Providing persuasive evidence that you have examined all relevant aspects and accounts associated with the accounts receivable.

3. Providing written documentation all about the findings and conclusions related to accounts receivable.

4. Write a memo stating your findings.

Relevant information:

- Account Receivable Confirmations have been conducted and the findings are included in the data obtained from the Company.

- Gross Amount is equal to $\$ 369,255.13$

- Goods and Services Tax is equal to $\$ 25,193.36$

- Provincial sales Tax is equal to $\$ 28,525.83$

- Date range $11 / 4 / 2018$ to $3 / 31 / 2019$

- Record count is 300

Submission requirements and order:

1. Memo (page one)

2. Printouts and supporting documents (evidence) (additional pages)

3. History (additional pages)

Data file and Link for MEMO example are located on D2L 


\section{PROJECTS AND PROCEDURES IN}

\section{IDEA}

\section{- IDEA PROJECTS:}

- Audit Documentation and Opinion

- STUDENT ARE PROVIDED LINKS TO DATA FILES

- LINKS TO PCAOB AS 3101 AND 3105

- PROJECT IS DESIGNED TO TIE ANALYSIS AND DOCUMENTATION TO OPINIONS

- BUILDS ON PREVIOUS WRITING PROJECTS

\section{Audit Documentation and Opinion}

\section{Introduction}

You have been engaged to conduct an objective assessment of the Company's financial statements. Generally Accepted Audit Standards (GAAS) require that you plan and perform the audit to obtain reasonable assurance about whether the financial statements are free from material misstatement. Your audit should be conducted with the objective of our expressing an opinion on the financial statements. As an auditor you need to document:

1. A statement briefly explaining your overall audit objective

2. Concisely document your tests and analysis of the financial statements provided. Clearly divide your documentation according to the tests performed.

3. Provide a concise, but informative analysis of each test using the following as a guide:

a. Tie the objective/assertion tested, procedure used to the results of the test. Explain what the results means to the financials or account/data tested (understated, overstated, agrees, implies bad debt, should be reclassified, etc.)

b. Proposed audit adjustments (reclassify negative accounts receivables as accounts payables, etc.).

c. Support your statements and proposed with evidence found in your analysis (numbers, accounts, results, etc.)

d. Provide evidence of your findings and recommendations with documentation such as printouts of your analysis, extractions, invoices, etc. Use a form of mapping or documentation such as the history, to show the reader where your evidence is located.

4. Write a formal opinion in good form regarding the presentation of the financial statements as a whole. Use the PCAOB websites listed below as a guide to writing an opinion. Do not leave blank spaces. 


\section{PROJECTS AND PROCEDURES IN IDEA}

- IDEA PROJECTS:

- Audit Documentation and Opinion

- RUBRIC USED TO GUIDE STUDENTS WRITING AND FOR GRADING.

- RUBRICS CAN BE EMBEDDED IN D2L.

- POST AN EVALUATION FOR THE Class OF COMMON ISSUES FOUND IN THE ASSIGNMENT AS OPPOSED TO INDIVIDUAL RESPONSES.

\begin{tabular}{|c|c|c|c|}
\hline $\begin{array}{l}\text { Rubric for Audit Write- } \\
\text { ups }\end{array}$ & Proficient & Adequate & Deficient \\
\hline Overall Audit Objective & $\begin{array}{l}\text { Audit purpose is } \\
\text { clear and } \\
\text { appropriately } \\
\text { defined. } \\
\text { Addresses } \\
\text { appropriate } \\
\text { audience and } \\
\text { business }\end{array}$ & $\begin{array}{l}\text { Purpose of audit is } \\
\text { not clear or } \\
\text { combined with } \\
\text { other objectives. } \\
\text { Audience or client } \\
\text { is not appropriate } \\
\text { or clear. }\end{array}$ & $\begin{array}{l}\text { Audit purpose is } \\
\text { missing or poorly } \\
\text { incorrectly } \\
\text { defined. } \\
\text { Audience or client } \\
\text { is not properly } \\
\text { addressed. }\end{array}$ \\
\hline General Writing & $\begin{array}{l}\text { Develops concise } \\
\text { Standard English } \\
\text { Sentences. } \\
\text { Writing is } \\
\text { essentially error- } \\
\text { free in terms of } \\
\text { spelling, grammar, } \\
\text { and MWR }\end{array}$ & $\begin{array}{l}\text { Word forms are } \\
\text { correct and } \\
\text { sentence structure } \\
\text { is effective. The } \\
\text { present tense is } \\
\text { effective } \\
\text { Minor errors in } \\
\text { spelling, grammar, } \\
\text { and MWR. }\end{array}$ & $\begin{array}{l}\text { Uses words that } \\
\text { are unclear and } \\
\text { sentence } \\
\text { structure in } \\
\text { inadequate. } \\
\\
\text { Writing contains } \\
\text { frequent errors in } \\
\text { spelling, grammar, } \\
\text { and MWR. }\end{array}$ \\
\hline Objectives & $\begin{array}{l}\text { Clear and } \\
\text { measurable } \\
\text { Tied clearly to one } \\
\text { assertion } \\
\text { Logically } \\
\text { supported with } \\
\text { sufficient and } \\
\text { appropriate } \\
\text { evidence } \\
\text { Effectively } \\
\text { connected to } \\
\text { documents }\end{array}$ & $\begin{array}{l}\text { Stated but may not } \\
\text { be clearly } \\
\text { measureable } \\
\text { adequate organized } \\
\text { to develop a } \\
\text { coherent argument } \\
\text { in support of an } \\
\text { assertion } \\
\text { sufficient and } \\
\text { appropriate } \\
\text { evidence is present } \\
\text { but may not be } \\
\text { adequate analyzed } \\
\text { or detailed } \\
\text { connections to } \\
\text { objectives, } \\
\text { assertions, and } \\
\text { evidence may be } \\
\text { weak }\end{array}$ & $\begin{array}{l}\text { objective are not } \\
\text { clearly or easily } \\
\text { measureable } \\
\text { not adequate } \\
\text { organized to } \\
\text { develop a } \\
\text { coherent } \\
\text { argument in } \\
\text { support of an } \\
\text { assertion } \\
\text { lacks sufficient } \\
\text { and appropriate } \\
\text { evidence or lacks } \\
\text { adequate analysis } \\
\text { or details } \\
\text { connections to } \\
\text { objectives, } \\
\text { assertions, and } \\
\text { evidence weak or } \\
\text { missing }\end{array}$ \\
\hline
\end{tabular}




\section{TIPS AND TRICKS}

- MAKE DATA ANALYSIS PART OF YOUR REGULAR LECTURE

- INTRODUCE SOFTWARE TO STUDENTS EARLY IN THE COURSE.

- GUIDE STUDENTS THROUGH THE DOWNLOADING AND INSTALLING PROCESS

- DEMONSTRATE THE SOFTWARE IN CLASS

- INCORPORATE DATA ANALYSIS DEMONSTRATIONS INTO DISCUSSIONS ON CYCLE CHAPTERS.

- HAVE EACH PROJECT BUILD ON THE PREVIOUS PROJECTS IN LEVEL OF DIFFICULTY AND RIGOR.

○ 


\section{TIPS AND TRICKS}

\section{BECOME AN ACADEMIC PARTNER:}

- REGISTERED FACULTY AND STUDENTS ARE PROVIDED FREE ACCESS TO THE EDUCATIONAL VERSION OF IDEA SOFTWARE AND DATA.

- https://academicportal.casewareanalytics.com/en/p ublic/student-registration

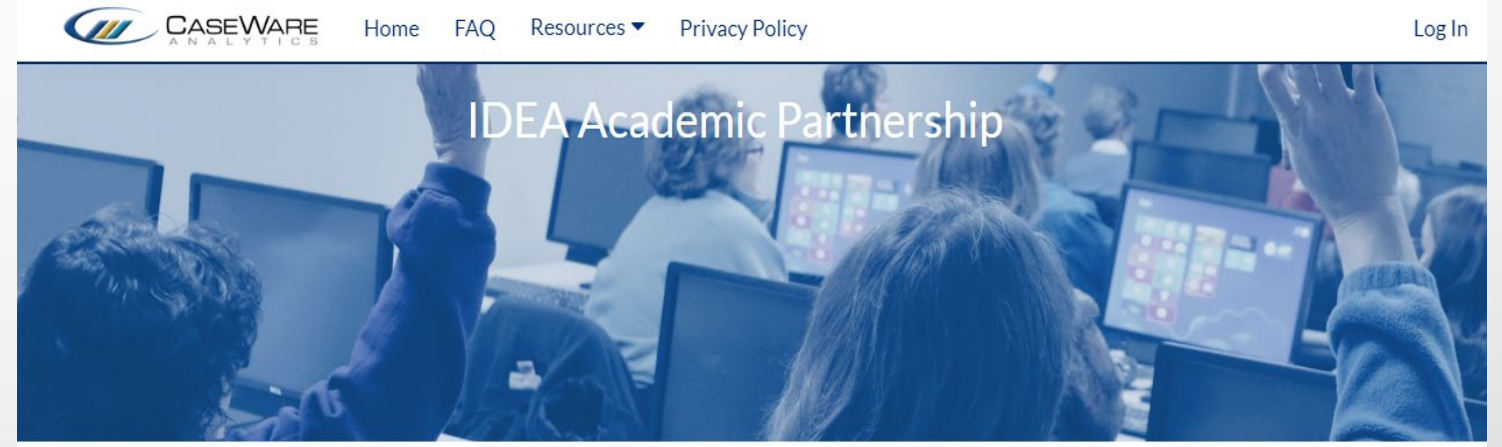

Student - Program Registration

Fill out the form below to complete your registration. *The field is mandatory

English Copyright 02020 CaseWare Analytics. All rights
reserved.

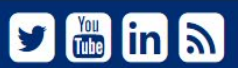




\section{TIPS AND TRICKS}

\section{GETTING STARTED:}

- REQUIRE THE SOFTWARE TO BE INSTALLED EARLY.

- RECORD AND POST A VIDEO DEMONSTRATING HOW TO DOWNLOAD AND INSTALL IDEA.

- HOST AN IN-CLASS CHECK-IN SESSION TO ASSIST WITH DOWNLOAD AND INSTALLATION ISSUES.

- CONNECT STUDENTS WITH FREE TRAINING SESSIONS AND VIDEO RESOURCES

- $\quad$ HTTPS://WWW.YOUTUBE.COM/WATCH2V=TVKWHAWBUCA

- $\quad$ HTTPS://WWW.YOUTUBE.COM/WATCH?V=HEZ49DPKQ44

- $\quad$ HTTPS://WWW.AUDIMATION.COM/TRAINING/GETTINGSTARTED-WITH-IDEA-IMPORTING-ANALYZING-DATA-W-200828/
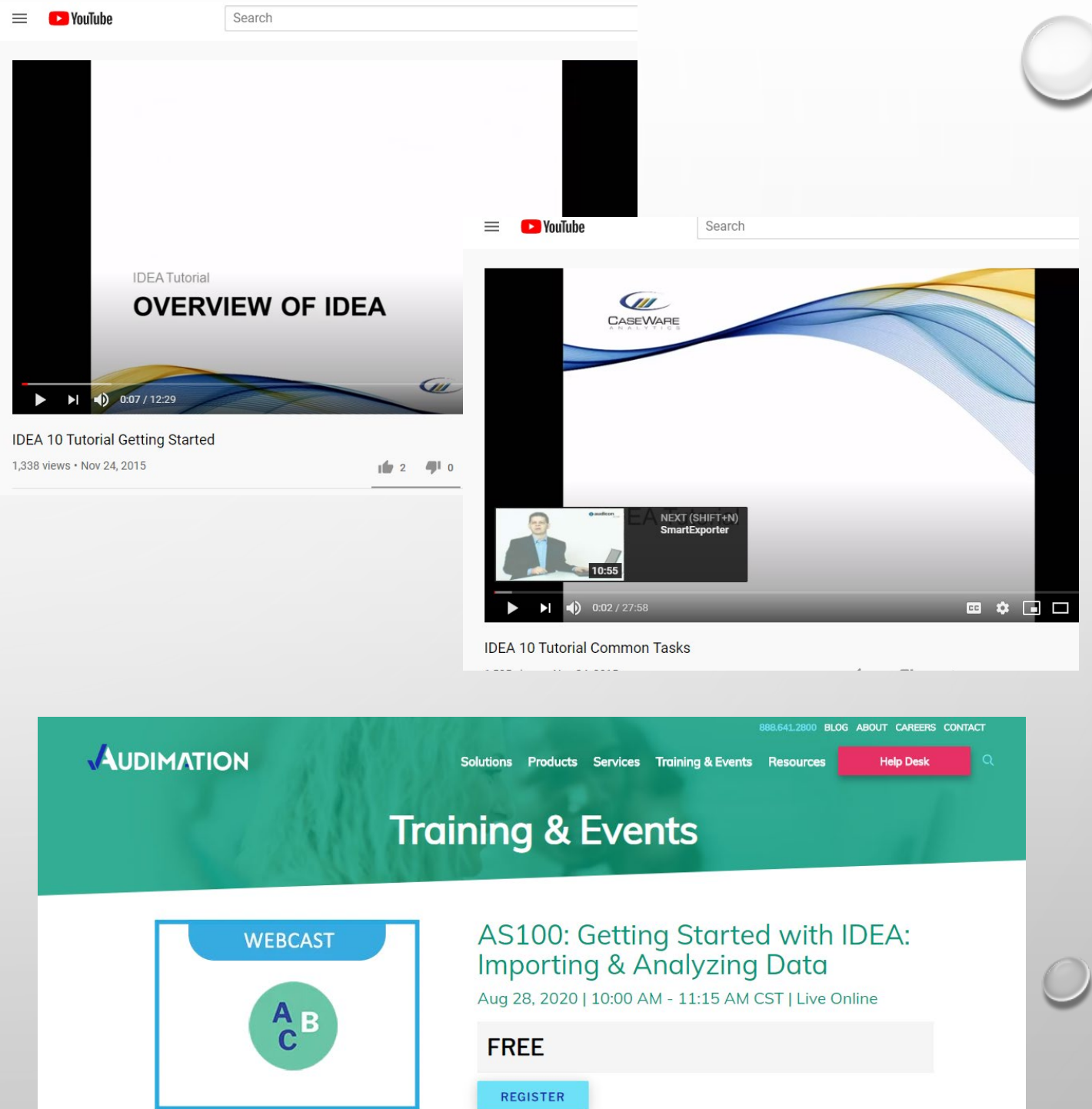

AS100: Getting Started with IDEA: Importing \& Analyzing Data

Aug 28, 2020 | 10:00 AM - 11:15 AM CST | Live Online

FREE

REGISTER

+ + Google calendar + iCal Export 


\section{TIPS AND TRICKS}

IN-CLASS GUIDED DEMONSTRATIONS HELP STUDENTS UNDERSTAND:

- HOW TO IMPORT FILES

- hOW tO TABULATE FIELD STATISTICS.

- how to tabulate CONTROl totals

- hOW TO SORT FILES

- HOW TO CREATE INDICES

- HOW TO EXTRACT DATA

- HOW TO SUMMARIZE DATA

- HOW TO AGE DATA.

IT ALSO PROVIDES THE OPPORTUNITY TO DEMONSTRATE HOW EVIDENCE CREATES A PICTURE OF WHAT IS GOING ON IN THE FINANCIAL STATEMENTS.

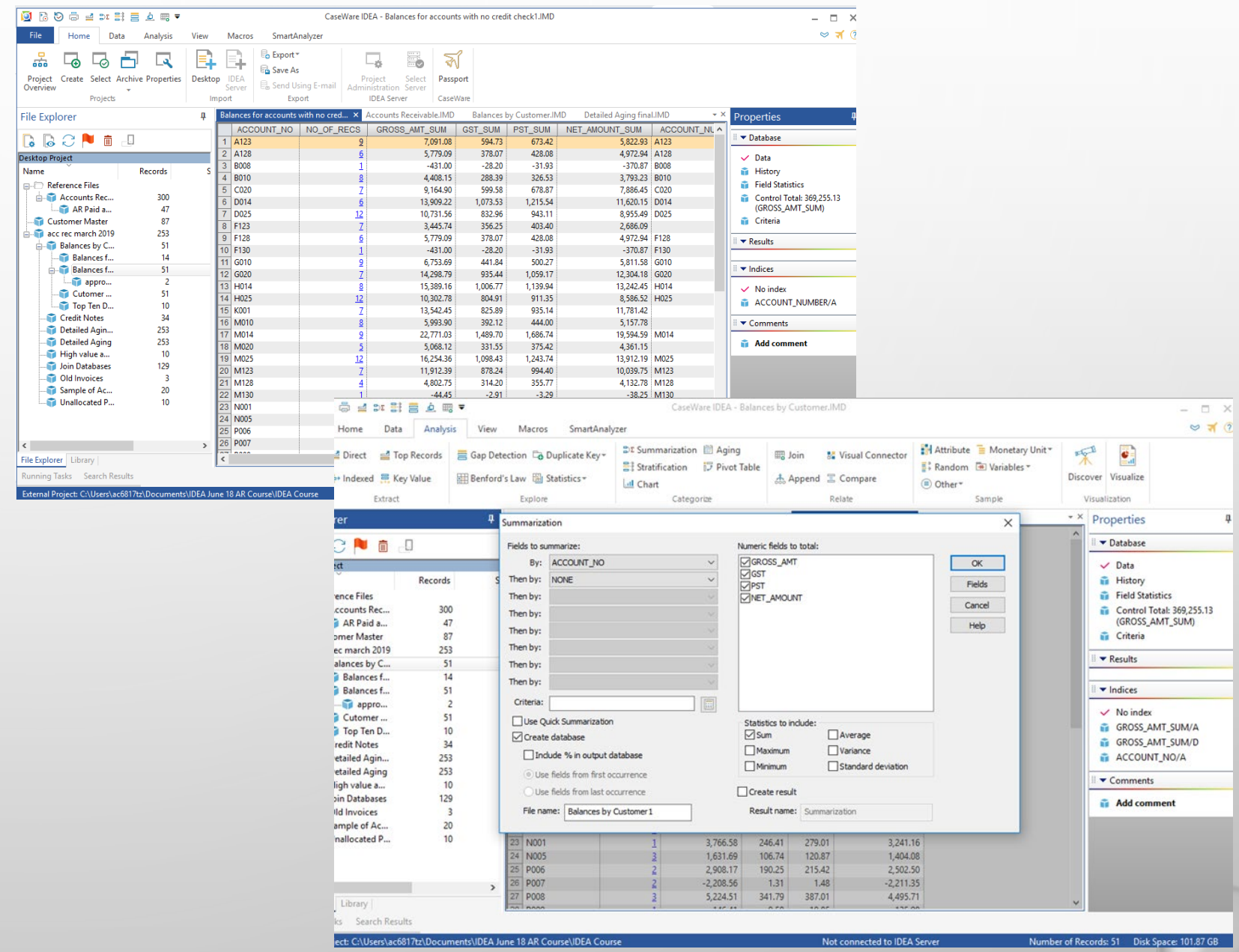

